\title{
Evaluating Sensitivity to Different Options and Parameterizations of a Coupled Air Quality Modelling System over Bogotá, Colombia. Part I: WRF Model Configuration
}

\author{
Beatriz Reboredo1, Raúl Arasa1, Bernat Codina ${ }^{1,2}$ \\ ${ }^{1}$ Air Quality Department, Meteosim S.L., Barcelona, Spain \\ ${ }^{2}$ Department of Astronomy and Meteorology, Barcelona, Spain \\ Email: breboredoviso@gmail.com, rarasa@meteosim.com, bcodina@ub.edu
}

Received 25 March 2015; accepted 10 April 2015; published 15 April 2015

Copyright (C) 2015 by authors and Scientific Research Publishing Inc.

This work is licensed under the Creative Commons Attribution International License (CC BY). http://creativecommons.org/licenses/by/4.0/

\section{(c) (i) Open Access}

\section{Abstract}

Meteorological inputs are of great importance when implementing an air quality prediction system. In this contribution, the Weather Research and Forecast (WRF-ARW) model was used to compare the performance of the different cumulus, microphysics and Planet Boundary Layer parameterizations over Bogotá, Colombia. Surface observations were used for comparison and the evaluated meteorological variables include temperature, wind speed and direction and relative humidity. Differences between parameterizations were observed in meteorological variables and Betts-Miller-Janjic, Morrison 2-moment and BouLac schemes proved to be the best parameterizations for cumulus, microphysics and PBL, respectively. As a complement to this study, a WRF-Large Eddy Simulation was conducted in order to evaluate model results with finer horizontal resolution for air quality purposes.

\section{Keywords}

Sensitivity Analysis, Air Quality Modelling, Meteorological Modelling, WRF, Physical Options

\section{Introduction}

Air quality is one of the main issues that are concerned by current atmospheric research. Global air pollution has an impact on human health, climate change and on the physics and chemistry of the atmosphere [1]. Air pollution has become one of the most important interests of the local authorities in Latin America and represents the 
greatest social and economic costs of environmental damage after water pollution and natural disasters in Colombia [2]. Urban agglomerations as Bogotá are major sources of regional and global atmospheric pollution with the pertinent environmental impact [3]. Bogotá $\left(4.6^{\circ} \mathrm{N}, 74.1^{\circ} \mathrm{W}\right)$ is the $5^{\text {th }}$ most populated city with around 7.4 million inhabitants in Latin America and one of most polluted cities [4], emissions from traffic linked to the increasing numbers of vehicles contribute to this concern [5] [6].

Air quality modelling has become a useful tool for administrations since it provides them a method to deal with human resources, production, emergency proceedings or to improve existing air quality plans and test abatement strategies [7]. There are several air pollution modelling studies in South America [8] [9] but none of them are developed in Colombia or nearby countries. There are a few works focused on Colombia [10] [11] which analyze sensitivity of a mesoscale meteorological model to couple with an emission model and with a photochemical model. Together, these three models compose an air quality modelling system [12]. Accordingly, implementing an air quality system in a particular area starts with setting up the meteorological model (the final aim of this study) which provides inputs for emission and photochemical models. The main interest of this work is to evaluate how the Weather Research and Forecasting (WRF) mesoscale meteorological model responses to different parameterizations during high air pollution episodes, and more specifically during days of high ozone concentrations in Bogotá.

Mesoscale meteorological models allow us to study and simulate meteorological variables. These models have a wide range of physical options to set up. It is a fundamental factor when configuring a model the selection of the physical parameterizations that are used to simplify somehow unresolved processes applying diverse approximations, the determination of the suitable model setup is one of the challenges when establishing a mesoscale model in a new region. Apart from the existence of a large array of available options, the best combination for one region is not necessarily applicable to another [13].

In this paper, we focus our attention on the meteorological modelling system. Exploring its sensitivity to variation in its configuration options, it is an important model evaluation exercise [14]. In terms of air quality applications, the simulated concentration depends on the accuracy of this meteorological model and the importance of meteorological inputs on air quality modelling has been clearly stated [15] [16] so this analysis allow us to reduce the total uncertainty associated to the air quality modelling system since meteorological outputs are inputs both in the emission and photochemical models. Few studies of WRF sensitivity to diverse parameterizations exist over tropical regions, and most of them are related to PBL parameterization schemes [17]-[19]. ARW (Advanced Research WRF) core has been used to obtain meteorological fields. Meteorological outputs were evaluated by means of statistical techniques. Numerical deterministic evaluation has been realized to compare modelling results with measurements.

Description of the studied area is presented in Section 2.1, as well as simulation domains and selected episodes. A characterization of the model and the methodology to evaluate it is presented in Sections 2.2 and 2.3, respectively. Detailed analysis of the experiments developed is presented in Section 2.4 and results obtained are presented in Section 3. Finally, some conclusions are reported in Section 4.

\section{Methodology}

In the following sections we show a more detailed description of the studied area features, the simulation domains and periods analyzed as well as a more comprehensive explanation of the modelling approach and model evaluation.

\subsection{Studied Area, Simulation Domains and Episodes Selected}

Following the aim of implementing an air quality modelling system in Colombia, Bogotá was chosen to perform WRF model sensitivity.

Bogotá is the capital of Colombia, the fourth biggest country in South America. It is divided into 32 departments and one capital district (Figure 1), Bogotá, the capital of the department of Cundinamarca and also treated as a department itself. Bogotá ranks fourth in the list of national capitals ordered by altitude with $2625 \mathrm{~m}$ above sea level. It lies in a $40 \mathrm{~km}$ wide and $100 \mathrm{~km}$ long plateau placed in one of the three Andean mountain ranges which cross the country. Mountainous complex terrain borders the high plateau. Its longest river is Bogotá River which has shown high pollution levels in recent years. Bogotá registers average yearly rainfall of $1013 \mathrm{~mm}$ and average yearly temperatures of $15^{\circ} \mathrm{C}$. 


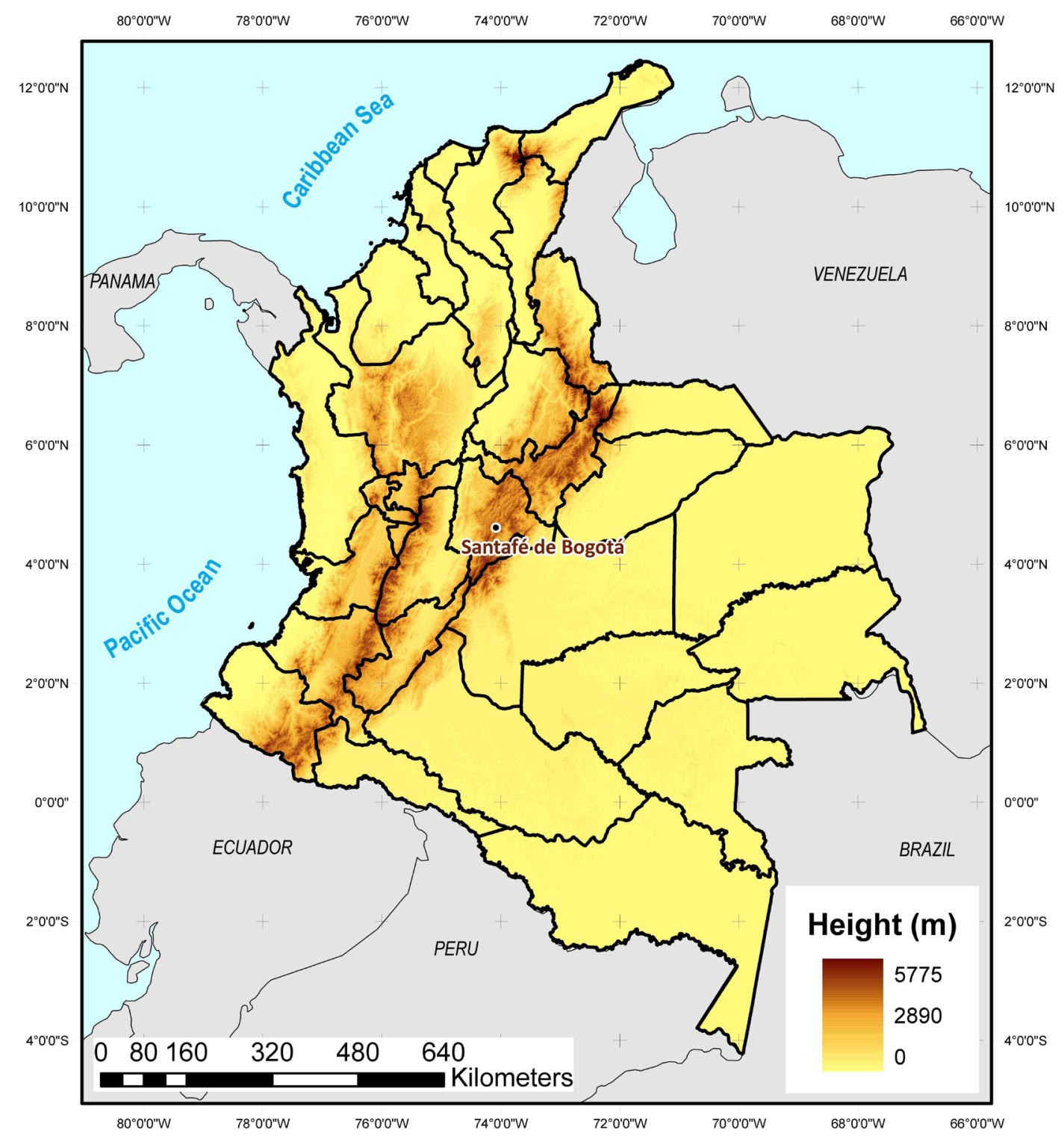

Figure 1. Main administrative divisions and topography map of Colombia [Image generated with ArcGIS].

In Figure 2, we show modelling domains used for simulations. The WRF model is built over a mother domain (D01) with $27 \mathrm{~km}$ spatial resolution, centered at $4.6^{\circ} \mathrm{N}, 74.1^{\circ} \mathrm{W}$. It comprises Central America, northern South America and part of Brazil and Peru, Pacific and Atlantic Oceans and Caribbean Sea and it is intended to capture synoptic features and general circulation patterns. The first nested domain (D02), with a spatial resolution of $9 \mathrm{~km}$, covers northwestern South America and part of the Caribbean Sea and Pacific Ocean. The third nested domain (D03), with a spatial resolution of $3 \mathrm{~km}$, comprises the Cundinamarca department and the fourth nested domain (D04) covers Bogotá. A fifth domain was included to take further the sensitivity analysis of WRF model at a higher resolution (WRF-Large Eddy Simulation): it is the innermost domain (D05), with a $333 \mathrm{~m}$ resolution. Table 1 shows the main characteristics of the simulation domains.

Simulations were conducted in 16 specific days of the year 2010 (1-2/01/2010; 5-6/01/2010; 13-14/02/2010; 27-28/02/2010; 21-22/08/2010; 11-12/09/2010; 1-2/04/2010, 11-12/12/2010). These days present ozone concentrations above $60 \mathrm{ppb}$ as a maximum running average over eight hours according to air pollution records supplied by the Red de Monitoreo y Calidad del Aire de Bogotá (RMCAB). 


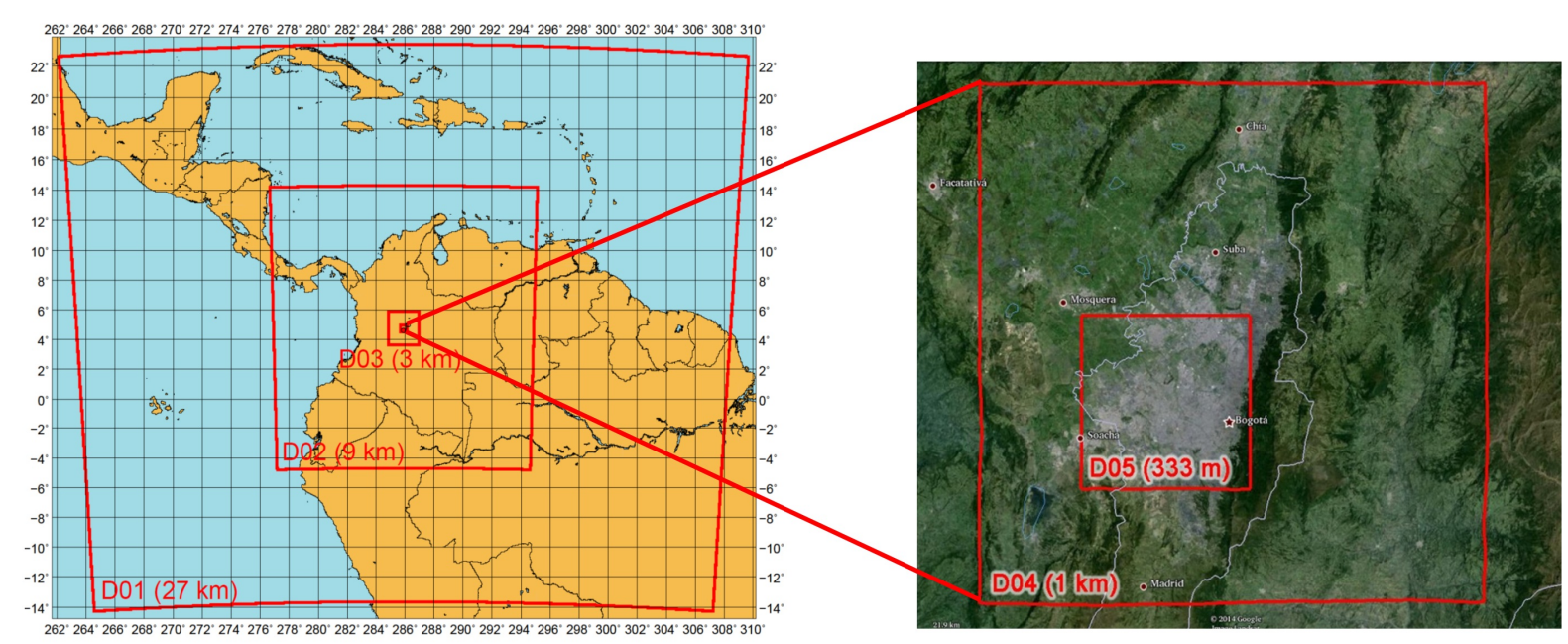

Figure 2. Modelling domains for simulations. [Image on the right generated using Google Earth].

Table 1. Simulation domains.

\begin{tabular}{|c|c|c|c|c|}
\hline Domain & Description & Resolution & Grid points & Domain Size \\
\hline D01 & Northern South America \& Central America & $27 \times 27 \mathrm{~km}^{2}$ & $187 \times 157$ & $5049 \times 4239 \mathrm{~km}^{2}$ \\
\hline D02 & North-western South America & $9 \times 9 \mathrm{~km}^{2}$ & $223 \times 238$ & $2007 \times 2142 \mathrm{~km}^{2}$ \\
\hline D03 & Cundinamarca & $3 \times 3 \mathrm{~km}^{2}$ & $79 \times 85$ & $237 \times 255 \mathrm{~km}^{2}$ \\
\hline D04 & Bogotá & $1 \times 1 \mathrm{~km}^{2}$ & $55 \times 55$ & $55 \times 55 \mathrm{~km}^{2}$ \\
\hline D05 & Bogotá-Centre & $333 \times 333 \mathrm{~m}^{2}$ & $55 \times 55$ & $18,315 \times 18,315 \mathrm{~m}^{2}$ \\
\hline
\end{tabular}

\subsection{Modelling Approach}

The Advanced Research WRF (WRF-ARWv3.5.1) mesoscale model developed by the National Center for Atmospheric Research (NCAR), USA, was the model chosen to conduct the simulations. It is a universally used community mesoscale model and a state-of-the-art atmospheric modelling system that is applicable for both meteorological research and numerical weather prediction. Different physical options that WRF offers can be combined in many different ways. Further details and description on this model appear in [20]. WRF has different parameterizations for microphysics, radiation (long and short wave), cumulus, surface layer, planetary boundary layer and land surface.

The initial and boundary conditions for domain D01 were supplied by the National Centers for Environmental Prediction and National Center for Atmospheric Research (NCEP/NCAR) Climate Forecast System Reanalysis (v1), with $0.5^{\circ}(\sim 55 \mathrm{~km} \times 55 \mathrm{~km})$ of spatial resolution and $6 \mathrm{~h}$ of temporal sampling. Numerical simulations are executed for 48 hours corresponding on every day selected, taking the first 24 hours as spin-up time to minimize the effects of initial conditions and in order to represent a complete diurnal cycle. This is a common practice in meteorological modelling for air quality applications [21].

Two-way nesting was used for the three external domains (D01, D02 and D03) and one-way nesting for D04 and D05. The vertical structure of the model includes 32 vertical layers covering the whole troposphere and a resolution decreasing slowly with height in order to allow low-level flow details to be captured. The first 20 levels are inside atmospheric boundary layer (below $1500 \mathrm{~m}$ ), with the first level at approximately 16 meters, and the domain top is about $100 \mathrm{hPa}$. The higher resolution close to the surface is a common practice in air quality studies in order to better represent the physical-chemical processes within de Atmospheric Boundary Layer [9] [12] [22]-[24]. A total of 224 simulations have been run during the project development-14 configurations $\times$ 16 simulations/configuration. Meteorological modelling system works operationally in a computing cluster owned by Meteosim S.L. with 25 nodes and more than 212 cores. 


\subsection{Datasets and Model Evaluation}

The evaluation performed is focused on the innermost domains, D04 and D05, since the final aim of this study is to find the best model setup for high resolution simulations. Meteorological observations were provided by 10 air quality stations that belong to the Red de Monitoreo y Calidad del Aire de Bogotá (RMCAB). Figure 3 shows the location of these stations and Figure 3(b) a brief description of each of them.

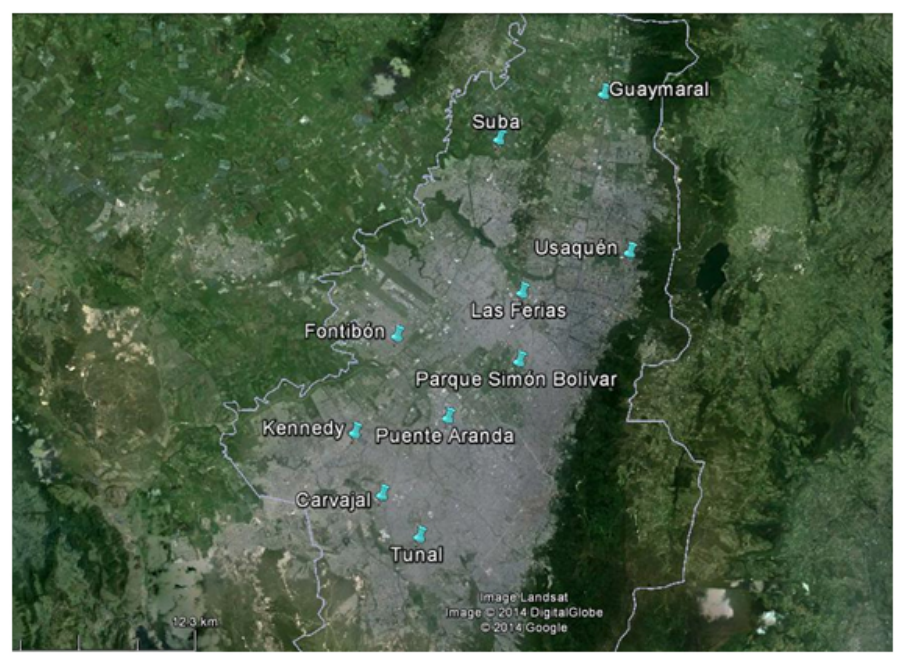

(a)

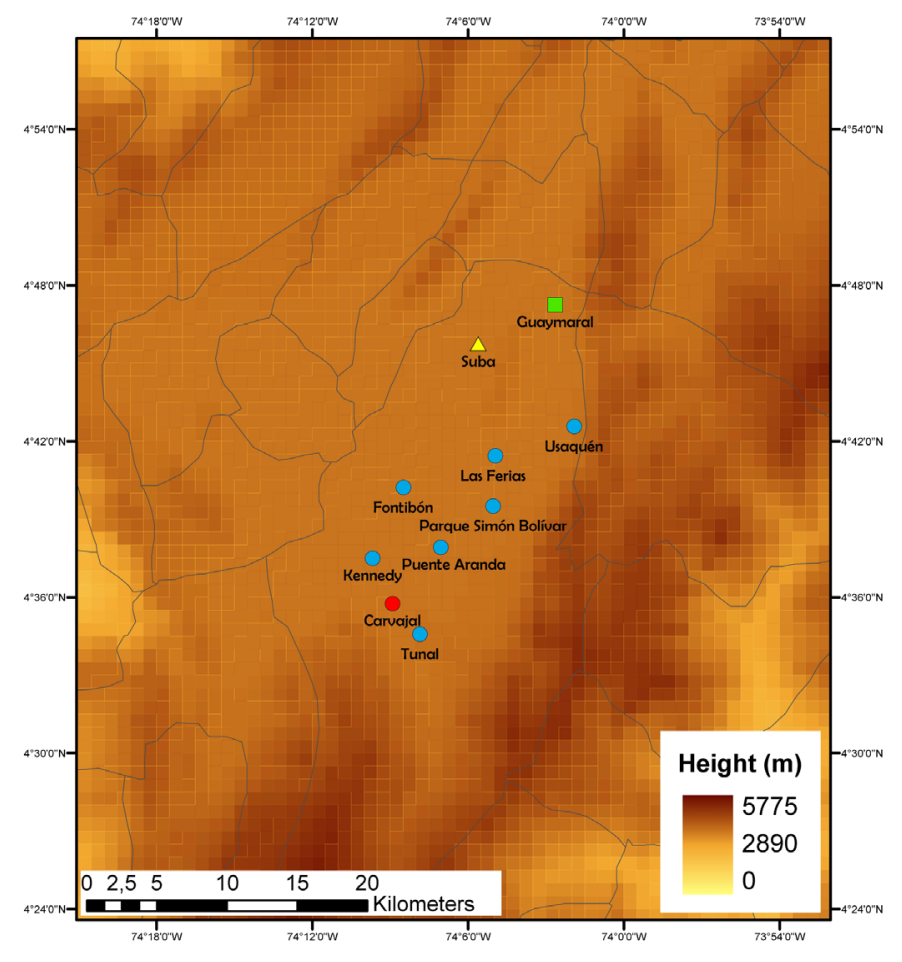

Stations

(Emission source / Location)

- Industry/Urban $\square$ Background/Rural

- Background/Urban $\triangle$ Background/Suburban

(b)

Figure 3. Meteorological stations used to conduct the analysis. [Images generated using Google Earth (a) and ArcGIS (b)]. 
There are several methodologies for model evaluation that all together complement themselves [25] [26]. The approach of comparing measurements with model results through different statistics (statistical deterministic approach) has been applied. The evaluations include the speed and wind direction at $10 \mathrm{~m}$ and air temperature and relative humidity at $2 \mathrm{~m}$. Temperature $(\mathrm{K})$ is calculated from WRF T2 predictions, wind speed $\left(\mathrm{m} \cdot \mathrm{s}^{-1}\right)$ and wind direction $\left(^{\circ}\right)$ are computed from U10 and V10 and relative humidity (\%) is obtained from Q2 (water mixing ratio at $2 \mathrm{~m}$ ), T2 and PSFC (surface pressure) using Magnus formula and specific humidity definition. The statistics have been calculated from hourly data of the model and observations, obtaining a global statistical value for the total period. These statistics provide information on how uncertain a model is in regard to the observations [27] and according to them a benchmark is given following Emery and Tai [28] suggestions. Table 2 shows the statistics used for model evaluation: the Mean Bias (MB), the Mean Absolute Gross Error (MAGE), the Root-Mean-Square Error (RMSE) and the Index of Agreement (IOA) and its benchmarks.

The circular nature of wind direction makes that statistical parameters should be carefully considered. Then, for the wind direction evaluation:

$$
\begin{gathered}
M B=\sum_{i=1}^{N} \frac{D}{N} \\
M A G E=\sum_{i=1}^{N} \frac{|D|}{N}
\end{gathered}
$$

$D$ represents the minimum difference between modelled values and observed ones and it is always between $-180^{\circ}$ and $+180^{\circ}$ and $N$ is the total number of measurements for all the days considered.

if $M_{i}<O_{i}$ :

$$
\begin{gathered}
D=\left(M_{i}-O_{i}\right) \text { if }\left|M_{i}-O_{i}\right|<\left|360+\left(M_{i}-O_{i}\right)\right| \\
D=360+\left(M_{i}-O_{i}\right) \text { if }\left|M_{i}-O_{i}\right|>\left|360+\left(M_{i}-O_{i}\right)\right|
\end{gathered}
$$

if $M_{i}>O_{i}$ :

$$
\begin{gathered}
D=\left(M_{i}-O_{i}\right) \text { if }\left|M_{i}-O_{i}\right|<\left|\left(M_{i}-O_{i}\right)-360\right| \\
D=\left(M_{i}-O_{i}\right)-360 \text { if }\left|M_{i}-O_{i}\right|>\left|\left(M_{i}-O_{i}\right)-360\right|
\end{gathered}
$$

[29] [30].

\subsection{Extent of the Sensitivity Analysis: Experiments}

Many different physics options in WRF are available for microphysics, radiation, surface layer, land surface, Planet Boundary Layer (PBL) and cumulus. Physics options (schemes) considered in our study are listed in Table 3. We focus our attention on the study of cumulus, microphysics and PBL schemes; and radiation and land surface schemes have been fixed for all configurations: Rapid Radiative Transfer Model (RRTM) as a longwave radiation scheme [31] and the Dudhia scheme as a shortwave radiation scheme [32]. One only option was tested as land-surface model (LSM): Noah LSM [33]. RRTM, Dudhia and Noah LSM schemes correspond to the default WRF physical options.

A total of 14 experiments have been evaluated progressively, as Table 4 shows. Three of them by varying cumulus parameterizations, two experiments by varying microphysics and a total number of eight by varying PBL schemes. We have focus most part of the configurations on PBL parameterizations due to the relevance of these schemes on air quality modelling [16]. Additionally, an experiment has been undertaken at a higher resolution to find out the effects on predictions when increasing horizontal resolution.

Cumulus parameterization is used to predict the collective effects of convective clouds at smaller scales as a function of larger-scale processes and conditions. First, three configurations, i.e. Default, $C 1$ and $C 2$, were analyzed to take out the best cumulus parameterization between Kain-Fritsch (KF) scheme [34] that has a deep and shallow convection sub-grid scheme, Betts-Miller-Janjic (BMJ) scheme [35] [36] that is the most popular for tropical systems and Grell-Freitas (GF) scheme that is a stochastic convective parameterization for air quality modelling [37]. 
Table 2. Statistics used for model evaluation.

\begin{tabular}{ccc}
\hline Meteorological parameter (reference height) & Statistic & Benchmark \\
\hline & MB & $< \pm 0.50 \mathrm{~K}$ \\
Temperature $(2 \mathrm{~m})$ & MAGE & $<2.00 \mathrm{~K}$ \\
& IOA & $\geq 0.80$ \\
\hline Wind speed $(10 \mathrm{~m})$ & MB & $\pm 0.50 \mathrm{~m} \cdot \mathrm{s}^{-1}$ \\
& RMSE & $<2.00 \mathrm{~m} \cdot \mathrm{s}^{-1}$ \\
Wind direction $(10 \mathrm{~m})$ & MB & $< \pm 10.00^{\circ}$ \\
& MAGE & $<30.00^{\circ}$ \\
\hline & MB & $<10.00 \%$ \\
\hline
\end{tabular}

Table 3. WRF schemes analyzed.

\begin{tabular}{|c|c|c|}
\hline Parameter & & Schemes \\
\hline \multirow[b]{3}{*}{$\begin{array}{c}\text { Planet Boundary Layer (PBL) } \\
\text { scheme-Surface Layer scheme }\end{array}$} & \multicolumn{2}{|c|}{$\begin{array}{ll}\text { - } & \text { Kain-Fritsch (KF) } \\
\text { - } & \text { Betts-Miller-Janjic (BMJ) } \\
\text { - } & \text { Grell-Freitas (GF) (new in v.3.5.1) }\end{array}$} \\
\hline & \multicolumn{2}{|c|}{$\begin{array}{ll}\text { - } & \text { WSM3 } \\
\text { - } & \text { Stony Brook University (SBU-YLin) } \\
\text { - } & \text { Morrison double-moment (Morrison 2-mom) }\end{array}$} \\
\hline & \multicolumn{2}{|c|}{$\begin{array}{ll}\text { - } & \text { Yonsei University (YSU)_Similarity theory MM5 (MM5 similarity) } \\
\text { - } & \text { Mellor-Yamada-Janjic (MYJ)_Eta similarity } \\
\text { - } & \text { Quasi-Normal Scale Elimination PBL (QNSE)_Similarity theory MM5 (MM5 similarity) } \\
\text { - } & \text { Assymetric Convective Model (ACM2) } \\
\text { - } & \text { Mellor-Yamada Nakanishi and Niino Level } 3 \text { (MYNN3)_Mellor-Yamada Nakanishi and Niino } \\
\text { - } & \text { GYNN) } \\
\text { - } & \text { BouLac PBL (BouLac)_Similarity theory MM5 (MM5 similarity) } \\
\text { - } & \text { UW-Similarity theory MM5 (MM5 similarity) } \\
\text { - } & \text { TEMF-TEMF surface layer }\end{array}$} \\
\hline Radiation & $\begin{array}{r}\text { Longwave } \\
\text { Shortwave }\end{array}$ & $\begin{array}{l}\text { - } \quad \text { Rapid Radiative Transfer model (RRTM) } \\
\text { - } \quad \text { Dudhia }\end{array}$ \\
\hline Land surface & - Noah & \\
\hline
\end{tabular}

Once cumulus option was selected, experiments $M 1$ and $M 2$ were evaluated together with the previous "best cumulus case” and with different Microphysics options. Microphysics parameterizations resolve water vapour, cloud and precipitation processes and that is the reason why they play such a significant role on air pollution levels [15]. The three microphysics schemes considered have been the WRF Single-Moment 3-class scheme (WSM3) [39], the Stony Book University (Y. Lin) scheme [39] and the Morrison double-moment scheme (Morrison 2-mom) described in [40].

Several authors have recently shown the impact of PBL parameterizations on air quality modelling applications. Some of these examples would be the [15] or [41] sensitivity analysis. Consequently, taking into consideration the future air quality applications of this contribution, more experiments were tested by varying PBL parameterizations. A total of nine PBL schemes are evaluated in this study. Once cumulus and microphysics options were selected, experiments $P 1, P 2, P 3, P 4, P 5, P 6, P 7$ and $P 8$ were tested together with the previous "best cumulus and microphysics case” and with different PBL options. The schemes to describe vertical sub-gridscale PBL fluxes due to eddy transport in the atmosphere are the Yonsei University (YU) PBL [42], the MellorYamada-Janjic (MYJ) PBL [35], the Assymetric Convective Model (ACM2) PBL [43], the Quasi-Normal Scale 
Table 4. Experiments developed and physics parameterizations. [Default configuration for default schemes in WRF].

\begin{tabular}{|c|c|c|c|c|c|c|c|}
\hline Configuration & Microphysics & $\begin{array}{c}\text { Longwave } \\
\text { radiation }\end{array}$ & $\begin{array}{c}\text { Shortwave } \\
\text { radiation }\end{array}$ & Surface Layer & $\begin{array}{l}\text { Land } \\
\text { Surface }\end{array}$ & $P B L$ & Cumulus \\
\hline Default & WSM3 & RRTM & Dudhia & $\begin{array}{c}\text { MM5 } \\
\text { similarity }\end{array}$ & Noah & YSU & KF \\
\hline$C 1$ & WSM3 & RRTM & Dudhia & $\begin{array}{c}\text { MM5 } \\
\text { similarity }\end{array}$ & Noah & YSU & BMJ \\
\hline$C 2$ & WSM3 & RRTM & Dudhia & $\begin{array}{c}\text { MM5 } \\
\text { similarity }\end{array}$ & Noah & YSU & GF \\
\hline M1 & SBU-YLin & RRTM & Dudhia & $\begin{array}{c}\text { MM5 } \\
\text { similarity }\end{array}$ & Noah & YSU & $\begin{array}{l}\text { Best cumulus } \\
\text { configuration } \\
\text { selected }\end{array}$ \\
\hline M2 & Morrisson 2-mom & RRTM & Dudhia & $\begin{array}{c}\text { MM5 } \\
\text { similarity }\end{array}$ & Noah & YSU & $\begin{array}{l}\text { Best cumulus } \\
\text { configuration } \\
\text { selected }\end{array}$ \\
\hline$P 1$ & $\begin{array}{l}\text { Best microphysics } \\
\text { configuration } \\
\text { selected }\end{array}$ & RRTM & Dudhia & Eta similarity & Noah & MYJ & $\begin{array}{c}\text { Best cumulus } \\
\text { configuration } \\
\text { selected }\end{array}$ \\
\hline $\mathbf{P 2}$ & $\begin{array}{l}\text { Best microphysics } \\
\text { configuration } \\
\text { selected }\end{array}$ & RRTM & Dudhia & $\begin{array}{c}\text { MM5 } \\
\text { similarity }\end{array}$ & Noah & ACM2 & $\begin{array}{l}\text { Best cumulus } \\
\text { configuration } \\
\text { selected }\end{array}$ \\
\hline P3 & $\begin{array}{l}\text { Best microphysics } \\
\text { configuration } \\
\text { selected }\end{array}$ & RRTM & Dudhia & QNSE & Noah & QNSE & $\begin{array}{l}\text { Best cumulus } \\
\text { configuration } \\
\text { selected }\end{array}$ \\
\hline P4 & $\begin{array}{l}\text { Best microphysics } \\
\text { configuration } \\
\text { selected }\end{array}$ & RRTM & Dudhia & MYNN & Noah & MYNN3 & $\begin{array}{l}\text { Best cumulus } \\
\text { configuration } \\
\text { selected }\end{array}$ \\
\hline P5 & $\begin{array}{l}\text { Best microphysics } \\
\text { configuration } \\
\text { selected }\end{array}$ & RRTM & Dudhia & $\begin{array}{c}\text { MM5 } \\
\text { similarity }\end{array}$ & Noah & GBM & $\begin{array}{l}\text { Best cumulus } \\
\text { configuration } \\
\text { selected }\end{array}$ \\
\hline P6 & $\begin{array}{l}\text { Best microphysics } \\
\text { configuration } \\
\text { selected }\end{array}$ & RRTM & Dudhia & $\begin{array}{c}\text { MM5 } \\
\text { similarity }\end{array}$ & Noah & BouLac & $\begin{array}{c}\text { Best cumulus } \\
\text { configuration } \\
\text { selected }\end{array}$ \\
\hline P7 & $\begin{array}{l}\text { Best microphysics } \\
\text { configuration } \\
\text { selected }\end{array}$ & RRTM & Dudhia & $\begin{array}{c}\text { MM5 } \\
\text { similarity }\end{array}$ & Noah & UW & $\begin{array}{l}\text { Best cumulus } \\
\text { configuration } \\
\text { selected }\end{array}$ \\
\hline$P 8$ & $\begin{array}{l}\text { Best microphysics } \\
\text { configuration } \\
\text { selected }\end{array}$ & RRTM & Dudhia & TEMF & Noah & TEMF & $\begin{array}{l}\text { Best cumulus } \\
\text { configuration } \\
\text { selected }\end{array}$ \\
\hline Best configuration & $\begin{array}{l}\text { Best microphysics } \\
\text { configuration } \\
\text { selected }\end{array}$ & RRTM & Dudhia & $\begin{array}{l}\text { SL selected } \\
\text { associated to the } \\
\text { best PBL conf. }\end{array}$ & Noah & $\begin{array}{c}\text { Best PBL } \\
\text { configuration } \\
\text { selected }\end{array}$ & $\begin{array}{l}\text { Best cumulus } \\
\text { configuration } \\
\text { selected }\end{array}$ \\
\hline M2-LES & $\begin{array}{c}\text { Morrisson } 2 \\
\text { moment }\end{array}$ & RRTM & Dudhia & $\begin{array}{c}\text { MM5 } \\
\text { similarity }\end{array}$ & Noah & LES & $\begin{array}{l}\text { Best cumulus } \\
\text { configuration } \\
\text { selected }\end{array}$ \\
\hline
\end{tabular}

Elimination (QNSE) PBL [44], the Mellor-Yamada Nakanishi and Niino Level 3 (MYNN3) PBL [45], the Grenier-Bretherton-McCaa (GBM) PBL [46] that is a TKE scheme new in the WRF version used for conduct these simulations, the Bougeault-Lacarrère (BouLac) PBL [47] that is a parameterization of orography-induced turbulence, the UW [48] and the Total Energy-Mass-Flux (TEMF) scheme [49]. The surface layer schemes calculate friction velocities and exchange coefficients that enable the calculation of surface heat and moisture fluxes by the land-surface models and surface stress in the planetary boundary layer scheme. These coefficients are computed by the similarity theory (MM5 similarity) surface layer scheme (described in [20]) for YSU, ACM2, GBM, BouLac and UW PBL schemes; similarity theory (Eta) surface layer scheme [36] for the MYJ PBL scheme and QNSE, MYNN and TEMF surface layer schemes for QNSE, MYNN3 and TEMF PBL schemes, respectively. 
As a result of the experiments evaluation and comparison, a model setup was chosen for prospective air quality applications in Bogotá. Additionally, we have included into the analysis, a modelling experiment with finer horizontal resolution (333 m) over Bogotá centre (D05). meteorological maximum horizontal resolution places a restriction on the maximum horizontal of coupled air quality modelling systems. In order to couple the different meteorological scales and to deal with the step from regional to local scale are a state-of-art topic in the atmospheric modelling science [50] and several approaches have been evaluated during the last years to solve this problem. Every approach uses different frameworks to characterize sub-grid features. WRF model includes several urban parameterizations as the Urban Canopy Model [51] or the Building Effect Parameterization [52]. Both of them present a major disadvantage because they need the use of detailed urban database. Moreover, WRF includes the possibility to use WRF with a large-eddy-simulation (LES) module that replaces the use of a traditional planetary boundary layer scheme. Other approaches are based on the coupling between air quality models indicated for different meteorological scales [53]-[55], or on a detailed monitoring of air quality levels to analyze sub-grid variability [56]. To complement this work, we have focus our attention in one of these approaches and a Large Eddy Simulation configuration has been run at a finer resolution (D05).

\section{Results and Discussion}

Results of the comparison of every configuration are presented below using the proposed statistics. They have been compared for each meteorological parameter; temperature, wind speed, wind direction and relative humidity, and the one that showed best results for the maximum meteorological parameters was selected as "best case". It is necessary to clarify that in the event of a "tie" or not conclusive differences, wind direction will carry the most sway when selecting "best case" due to the importance of this variable in air quality modelling.

\subsection{Cumulus Schemes}

The first schemes analyzed have been cumulus. Wind direction errors are not within the benchmark for any of the simulations ran. Terrain complexity has a considerable influence on wind direction errors and the values found are substantially above the MB and MAGE benchmarks. However, these values were found in similar studies [12] [15] [16] [29]. For the rest of the parameters, all of them follow the recommendation value (except wind speed RMSE for $C 1\left(2.17 \mathrm{~m} \cdot \mathrm{s}^{-1}\right)$ and $C 2\left(2.15 \mathrm{~m} \cdot \mathrm{s}^{-1}\right)$ configurations).

The three schemes produced similar results for temperature, with all values within the benchmarks and slightly overpredicting it. The $C 2$ configuration produced the lowest $\mathrm{MB}$ for temperature $(0.07 \mathrm{~K})$ while the lowest MAGE (1.67 K) and highest IOA (0.91) corresponded to Default configuration, even though no significant differences are observed between them, as can be seen in Table 5 . As for wind speed, $C 1$ and $C 2$ produced similar MB and RMSE values, it is the Default configuration which minimized wind speed MB $\left(0.16 \mathrm{~m} \cdot \mathrm{s}^{-1}\right)$ and

Table 5. Statistical evaluation. Results for configurations by varying cumulus schemes. Results within the benchmark are highlighted in bold, and the best for each statistic is shaded in gray.

\begin{tabular}{|c|c|c|c|c|}
\hline \multirow{2}{*}{$\begin{array}{c}\text { Meteorological } \\
\text { parameter }\end{array}$} & \multirow{2}{*}{ Statistic and benchmark } & \multicolumn{3}{|c|}{ WRF Configuration } \\
\hline & & Default & $C 1$ & $C 2$ \\
\hline \multirow{3}{*}{ Temperature } & $\mathrm{MB}(\mathrm{K})< \pm 0.50$ & 0.29 & 0.13 & 0.07 \\
\hline & MAGE $(\mathrm{K})<2.00$ & 1.67 & 1.68 & 1.68 \\
\hline & $\mathrm{IOA} \geq 0.80$ & 0.91 & 0.90 & 0.90 \\
\hline \multirow{2}{*}{ Wind speed } & $\mathrm{MB}\left(\mathrm{m} \cdot \mathrm{s}^{-1}\right)< \pm 0.50$ & 0.16 & 0.35 & 0.37 \\
\hline & $\operatorname{RMSE}\left(\mathrm{m} \cdot \mathrm{s}^{-1}\right)<2.00$ & 1.90 & 2.17 & 2.15 \\
\hline \multirow{2}{*}{ Wind direction } & $\operatorname{MB}\left({ }^{\circ}\right)< \pm 10.00$ & -13.27 & -9.30 & -13.08 \\
\hline & $\operatorname{MAGE}\left({ }^{\circ}\right)<30.00$ & 70.79 & 66.43 & 73.45 \\
\hline \multirow{3}{*}{ Relative humidity } & $\mathrm{MB}(\%)< \pm 10.00$ & -0.62 & 1.00 & 0.31 \\
\hline & MAGE $(\%)<20.00$ & 10.81 & 10.45 & 11.02 \\
\hline & $\mathrm{IOA} \geq 0.60$ & 0.79 & 0.80 & 0.79 \\
\hline
\end{tabular}


wind speed RMSE $\left(1.90 \mathrm{~m} \cdot \mathrm{s}^{-1}\right)$. Nevertheless, it is $C 1$ configuration which produced the lowest MB $\left(-9.30^{\circ}\right)$ and MAGE $\left(66.43^{\circ}\right)$ for wind direction, and the lowest MAGE $(10.45 \%)$ and highest IOA (0.80) for relative humidity. According to the results shown in Table 5 and wind statistics for wind direction, the cumulus parameterization of $C 1$ (BMJ cumulus scheme) configuration provides the optimum results. For this reason BMJ was selected for next simulations to come as cumulus scheme.

Graphics in Figure 4 [left] reflect the mean daily temperature evolution (a), the mean daily wind speed evolu-

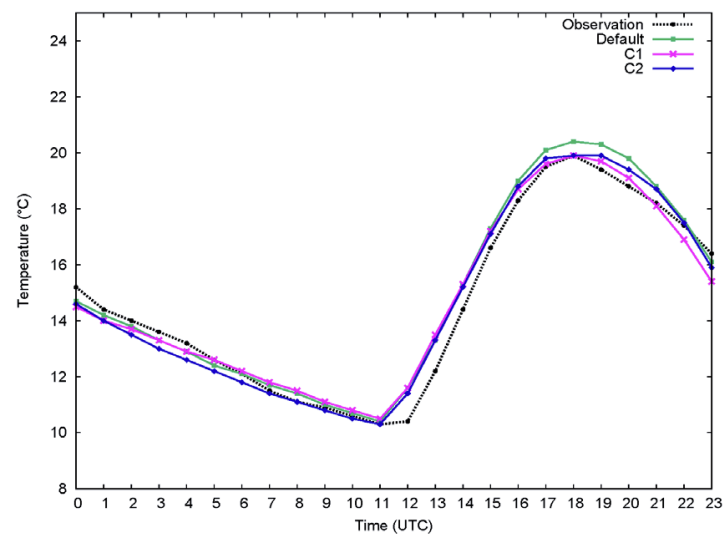

(a)

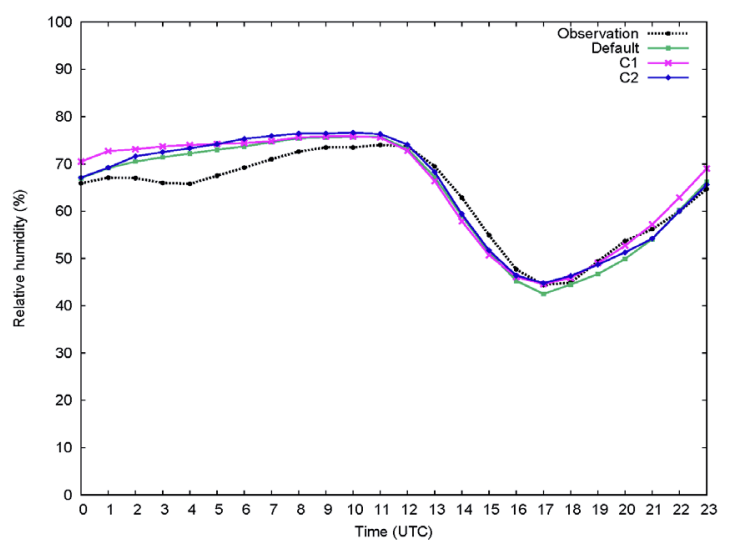

(c)

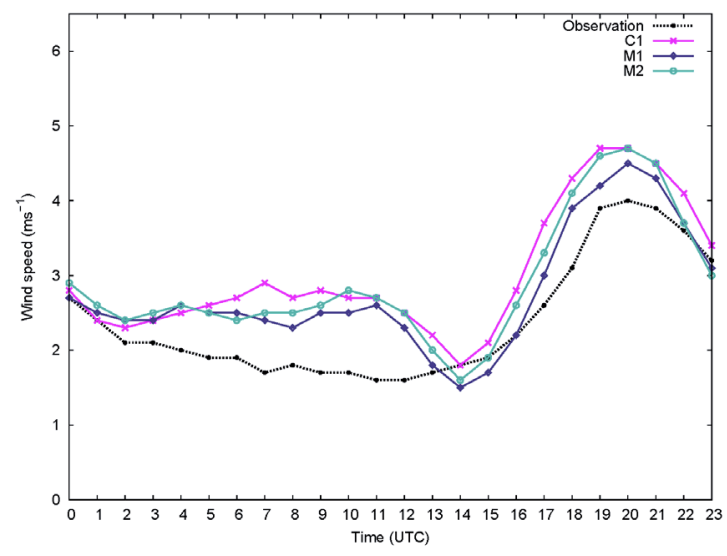

(e)

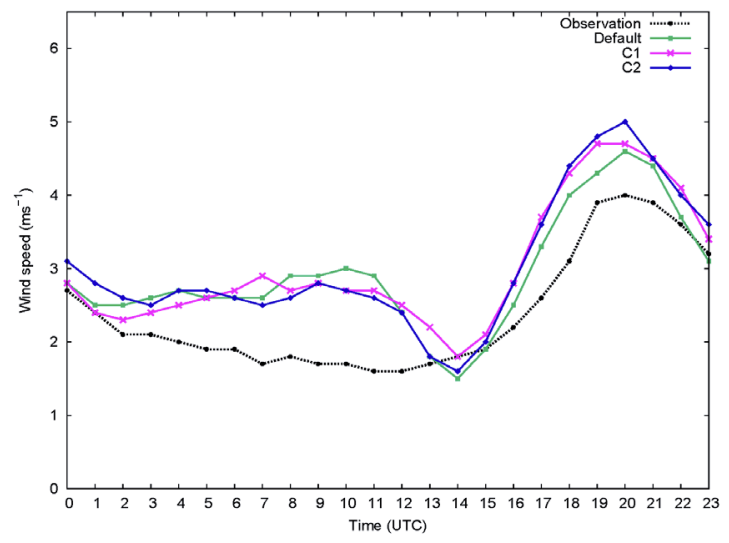

(b)

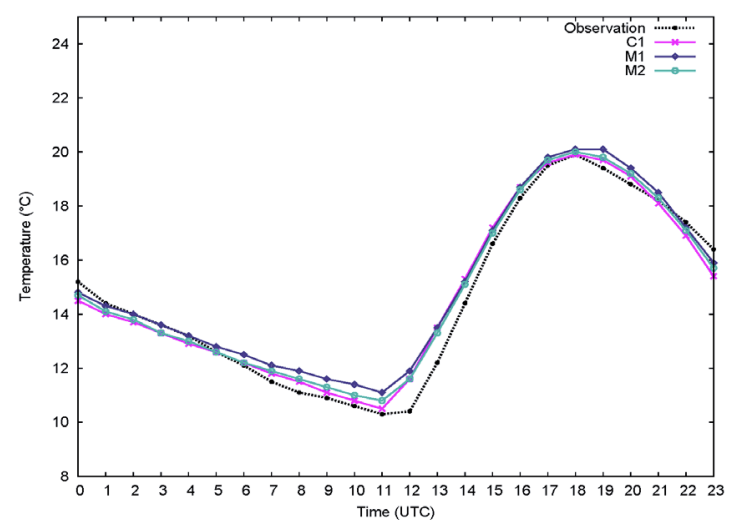

(d)

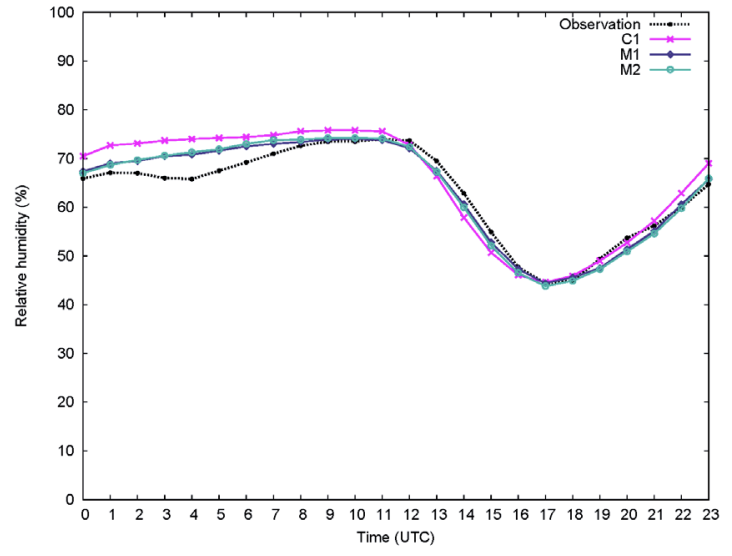

(f)

Figure 4. Daily evolution of the mean hourly temperature (a); wind speed (b) and relative humidity (c) for cumulus experiments [left] and hourly evolution of temperature (d); wind speed (e) and relative humidity (f) for microphysics experiments [right]. 
tion (b) and the mean daily relative humidity evolution (c) for Default, $C 1$ and $C 2$ configurations comparing with the same observed parameters. $C 1$ and C2 show a good prediction for maximum temperature while Default overestimates it. As it can be seen in Figure 4(b), wind speed tends to be overestimated for all configurations in general and in Figure 4(c), we find out that all the configurations reproduce well relative humidity profile.

\subsection{Microphysics Schemes}

Once BMJ cumulus parameterization was selected, three configurations were compared with this setting and by varying microphysics schemes: previous $C 1$ "cumulus best case" using WSM3 microphysics scheme, $M 1$ configuration with SBU-YLin and M2 using Morrison 2-moment.

Results for the three configurations with different microphysics schemes tested are shown in Table 6. The $C 1$ configuration produced the lowest MB for temperature $(0.13 \mathrm{~K})$ while the lowest MAGE $(1.64 \mathrm{~K})$ corresponded to $M 2$ configuration, while no conclusive differences where found for IOA for this parameter. $M 1$ minimized wind speed MB $\left(0.08 \mathrm{~m} \cdot \mathrm{s}^{-1}\right)$ and wind speed RMSE $\left(1.84 \mathrm{~m} \cdot \mathrm{s}^{-1}\right)$. If we focus on wind direction, it is also $C 1$ which produced the lowest MB $\left(-9.30^{\circ}\right)$ but not the lowest MAGE $\left(66.32^{\circ}\right)$ which is given by $M 2$ configuration. Likewise, even though no significant differences were found for MAGE for relative humidity, M2 presented the lowest MAGE (10.34\%) and highest IOA (0.80) together with $C 1$. Although microphysics parameterization is considered to be highly influential for precipitation outputs and therefore wet deposition predictions [57], results for relative humidity are quite similar in three configurations (Table 6 and Figure 4(f)). According to these results, the better overall description was given by the Morrisson 2-moment microphysics parameterization that belongs to $M 2$ configuration.

Graphics in Figure 4 [right] reflect the mean daily temperature evolution (d), the mean daily wind speed evolution (e) and the mean daily relative humidity evolution (f) for $C 1, M 1$ and $M 2$ configurations comparing with the same observed parameters. Graphic for temperature (Figure 4(d)) shows that microphysics does not affect temperature profile significantly because similar results are observed for $C 1, M 1$ and $M 2$. Figure 4(e) shows that wind speed tends to be overestimated for all configurations.

\subsection{PBL Schemes}

The last evaluation of WRF physics options involves PBL parameterizations. Once Morrison-2moment microphysics parameterization was set for the next configurations as a result of the $C 1, M 1$ and $M 2$ experiments, other nine configurations were compared with this microphysics scheme and by varying PBL parameterizations as Table 4 summarize. Results are shown in Table 7. P6 produced the lowest MB $(0.02 \mathrm{~K})$ for temperature while $M 2$ did the same with MAGE (1.64 K). PBL is also influential for wind speed, a parameter lightly overpredicted under all the PBL configurations tested. $P 4$ reduced the MB $\left(0.07 \mathrm{~ms}^{-1}\right)$ and RMSE $\left(1.73 \mathrm{~ms}^{-1}\right)$ for wind speed. It is quite clear that $P 6$ is the scheme that showed the best MAGE results for wind direction $\left(57.24^{\circ}\right)$ reducing by up to $12 \%$ the average $\mathrm{MB}$ for all configurations $\left(65.38^{\circ}\right)$. $P 6$ also minimized relative humidity $\mathrm{MB}(0.26 \%)$ and relative humidity MAGE (9.30\%) and improved the results of relative humidity IOA (0.82) with values of the three metrics that did not show important differences with $P 5 . P 8$ produced the worst results for all the metrics calculated for temperature, wind direction MAGE and both relative humidity MAGE and IOA with remarkable variation between configurations (up to $18.73^{\circ}$ difference in terms of wind direction MAGE and 0.17 difference in terms of wind direction IOA if we compare both with $P 6$ ). According to this, $P 6$ proved to be the best configuration improving the results for wind direction and relative humidity. Graphics in Figure 5 [left] show the mean daily temperature evolution (a), the mean daily wind speed evolution (b) and the mean daily relative humidity evolution (c) for $M 2, P 1, P 2, P 3, P 4, P 5, P 6, P 7$ and $P 8$ configurations comparing with the same observed parameters. $P 6$ is the best configuration in forecasting maximum wind speed and $P 8$ the worst one. Almost all configurations accurately predict temperature, with the exception of $P 8$, and the same conclusion can be drawn for relative humidity, for which $P 8$ continues to show the worst results with the TEMF Planet Boundary Layer scheme.

P2 (ACM2 PBL scheme), P4 (MYNN3 PBL scheme), P6 (BouLac PBL scheme) and P8 (TEMF scheme) configurations turned to be computationally more expensive than the others (about 30\% - 40\%) and P7 (UW scheme) up to $120 \%$. In the later case, this can be explained by a reduction of the time step from $60 \mathrm{~s}$ to $40 \mathrm{~s}$ due to computational errors. 
Table 6. Statistical evaluation. Results for configurations by varying microphysics schemes. Results within the benchmark are highlighted in bold, and the best for each statistic is shaded in gray.

\begin{tabular}{|c|c|c|c|c|}
\hline \multirow{2}{*}{$\begin{array}{l}\text { Meteorological } \\
\text { parameter }\end{array}$} & \multirow{2}{*}{ Statistic and benchmark } & \multicolumn{3}{|c|}{ WRF Configuration } \\
\hline & & $C 1$ & M1 & M2 \\
\hline \multirow{3}{*}{ Temperature } & $\mathrm{MB}(\mathrm{K})< \pm 0.50$ & 0.13 & 0.41 & 0.18 \\
\hline & MAGE $(\mathrm{K})<2.00$ & 1.68 & 1.69 & 1.64 \\
\hline & $\mathrm{IOA} \geq 0.80$ & 0.90 & 0.90 & 0.90 \\
\hline \multirow{2}{*}{ Wind speed } & $\operatorname{MB}\left(\mathrm{m} \cdot \mathrm{s}^{-1}\right)< \pm 0.50$ & 0.35 & 0.08 & 0.22 \\
\hline & $\operatorname{RMSE}\left(\mathrm{m} \cdot \mathrm{s}^{-1}\right)<2.00$ & 2.17 & 1.84 & 2.01 \\
\hline \multirow{2}{*}{ Wind direction } & $\operatorname{MB}\left({ }^{\circ}\right)< \pm 10.00$ & -9.30 & -12.54 & -10.01 \\
\hline & $\operatorname{MAGE}\left({ }^{\circ}\right)<30.00$ & 66.43 & 66.76 & 66.32 \\
\hline \multirow{3}{*}{ Relative humidity } & MB $(\%)< \pm 10.00$ & 1.00 & -0.74 & -0.79 \\
\hline & MAGE $(\%)<20.00$ & 10.45 & 10.74 & 10.34 \\
\hline & $\mathrm{IOA} \geq 0.60$ & 0.80 & 0.78 & 0.80 \\
\hline
\end{tabular}

Table 7. Statistical evaluation. Results for configurations by varying PBL schemes. Results within the benchmark are highlighted in bold, and the best for each statistic is shaded in gray.

\begin{tabular}{|c|c|c|c|c|c|c|c|c|c|c|}
\hline \multirow{2}{*}{$\begin{array}{l}\text { Meteorological } \\
\text { parameter }\end{array}$} & \multirow{2}{*}{ Statistic and benchmark } & \multicolumn{9}{|c|}{ WRF Configuration } \\
\hline & & M2 & $\mathbf{P 1}$ & $P 2$ & P3 & P4 & P5 & $P 6$ & P7 & P8 \\
\hline \multirow{3}{*}{ Temperature } & $\mathrm{MB}(\mathrm{K})< \pm 0.50$ & 0.18 & -0.25 & 0.30 & -0.46 & -0.32 & 0.06 & 0.02 & -0.05 & -0.97 \\
\hline & $\operatorname{MAGE}(\mathrm{K})<2.00$ & 1.64 & 1.71 & 1.69 & 1.77 & 1.74 & 1.68 & 1.73 & 1.69 & 2.20 \\
\hline & $\mathrm{IOA} \geq 0.80$ & 0.90 & 0.89 & 0.90 & 0.90 & 0.89 & 0.90 & 0.89 & 0.90 & 0.81 \\
\hline \multirow{2}{*}{ Wind speed } & $\operatorname{MB}\left(\mathrm{m} \cdot \mathrm{s}^{-1}\right)< \pm 0.50$ & 0.22 & 1.01 & 0.68 & 1.13 & 0.07 & 0.41 & 0.41 & 0.25 & 0.48 \\
\hline & $\operatorname{RMSE}\left(\mathrm{m} \cdot \mathrm{s}^{-1}\right)<2.00$ & 2.01 & 2.40 & 2.26 & 2.53 & 1.73 & 1.95 & 2.27 & 1.89 & 2.06 \\
\hline \multirow{2}{*}{ Wind direction } & $\operatorname{MB}\left({ }^{\circ}\right)< \pm 10.00$ & -10.01 & -1.78 & -13.40 & -10.97 & -10.66 & -12.12 & -7.06 & -6.14 & 0.60 \\
\hline & $\operatorname{MAGE}\left({ }^{\circ}\right)<30.00$ & 66.32 & 65.39 & 62.62 & 70.63 & 64.02 & 61.48 & 57.24 & 64.74 & 75.97 \\
\hline \multirow{3}{*}{ Relative humidity } & MB $(\%)< \pm 10.00$ & -0.79 & 4.22 & -1.42 & 3.11 & 2.80 & 0.61 & 0.26 & 1.59 & 9.06 \\
\hline & MAGE $(\%)<20.00$ & 10.34 & 10.51 & 10.24 & 10.71 & 10.17 & 9.48 & 9.30 & 9.96 & 15.09 \\
\hline & $\mathrm{IOA} \geq 0.60$ & 0.80 & 0.78 & 0.81 & 0.80 & 0.81 & 0.82 & 0.82 & 0.80 & 0.65 \\
\hline
\end{tabular}

\subsection{LES (Bogotá-333 m Resolution)}

A finer-grid LES covering a smaller horizontal domain (D05) is nested inside a coarser-grid covering a larger horizontal domain (D04). This last contribution aims to validate the model results by increasing the resolution so that a future coupling of the meteorological model and the photochemichal model would be interesting in terms of air quality applications. M2 configuration was selected to run LES simulation because cumulus and microphysics parameterizations were already evaluated obtaining the best results. M2-LES is compared with $M 2$ for a smaller domain (D05) so that validation is consistent including the same stations.

Comparisons between M2-LES configuration and M2 configuration within the D05 are shown in Table 8 and Figure 5 [right]. Even though M2 (D05) improved most metrics for all the meteorological parameters, there are not conclusive differences between them and this is an interesting outcome as it would allow us to apply WRF-LES approach to forecast air quality at an urban scale without deteriorating the quality of results. Figure 6 displays a wind flow comparison between M2 (D05) and M2-LES. This figure shows that by increasing reso- 

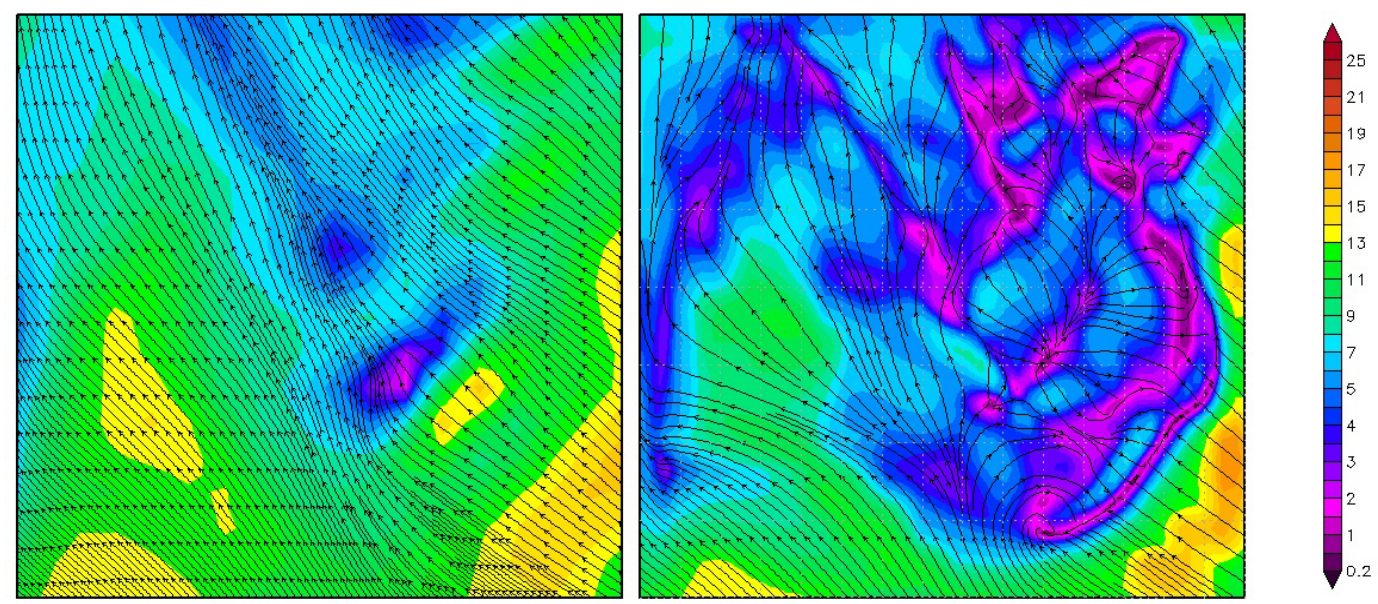

Figure 5. Wind flow maps $10 \mathrm{~m}_{\left(\mathrm{ms}^{-1}\right)}$ 21/08/2010 18 UTC. M2 (D05) [left] and M2-LES [right].

Table 8. Statistical evaluation for M2 configuration (M2-LES and M2 (D05) comparison). Results within the benchmark are highlighted in bold, and the best for each statistic is shaded in gray.

\begin{tabular}{|c|c|c|c|}
\hline \multirow{2}{*}{ Meteorological parameter } & \multirow{2}{*}{ Statistic and benchmark } & \multicolumn{2}{|c|}{ WRF Configuration } \\
\hline & & M2-LES (D05) & M2 (D05) \\
\hline \multirow{3}{*}{ Temperature } & $\operatorname{MB}(\mathrm{K})< \pm 0.50$ & 0.65 & 0.36 \\
\hline & MAGE $(\mathrm{K})<2.00$ & 1.43 & 1.32 \\
\hline & $\mathrm{IOA} \geq 0.80$ & 0.93 & 0.94 \\
\hline \multirow{2}{*}{ Wind speed } & $\mathrm{MB}\left(\mathrm{m} \cdot \mathrm{s}^{-1}\right)< \pm 0.50$ & -0.60 & -0.26 \\
\hline & $\operatorname{RMSE}\left(\mathrm{m} \cdot \mathrm{s}^{-1}\right)<2.00$ & 1.58 & 1.61 \\
\hline \multirow{2}{*}{ Wind direction } & $\operatorname{MB}\left({ }^{\circ}\right)< \pm 10.00$ & 0.39 & -6.98 \\
\hline & $\operatorname{MAGE}\left({ }^{\circ}\right)<30.00$ & 65.24 & 66.61 \\
\hline \multirow{3}{*}{ Relative humidity } & MB $(\%)< \pm 10.00$ & -0.30 & -0.73 \\
\hline & MAGE (\%) < 20.00 & 9.91 & 9.87 \\
\hline & $\mathrm{IOA} \geq 0.60$ & 0.81 & 0.82 \\
\hline
\end{tabular}

lution with LES approach, we find similar wind direction patterns and lower wind speed values for the same area at a higher resolution.

\section{Conclusions}

A total of thirteen WRF sensitivity experiments were conducted over Bogotá by varying cumulus, microphysics and Planet Boundary layer schemes during high air pollution episodes of 2010 and aiming to find the optimal setup of the model over this region. This work has focused most part of the configurations on PBL parameterizations due to its relevance on air quality modelling. We evaluate the differences in meteorological parameters of temperature, wind and relative humidity compared with observations in the innermost domain following a statistical analysis and the results show that no significant differences were found for temperature and relative humidity predictions depending on microphysics and cumulus parameterizations and no configuration perfectly works for all the variables. Among all the configurations analyzed, the best for the maximum meteorological parameters and selected as "best case" for cumulus, microphysics and PBL, proved to be P6, which improves the results for wind direction MAGE (57.24 $)$ and relative humidity MB (0.26\%), MAGE (9.30\%) and IOA (0.82). P6 has Betts-Miller-Janjic as cumulus scheme, the popular cumulus parameterization for tropical systems, Morrison 2-moment as microphysics scheme and Bougeault-Lacarrère (BouLac) as PBL scheme, a parameter- 


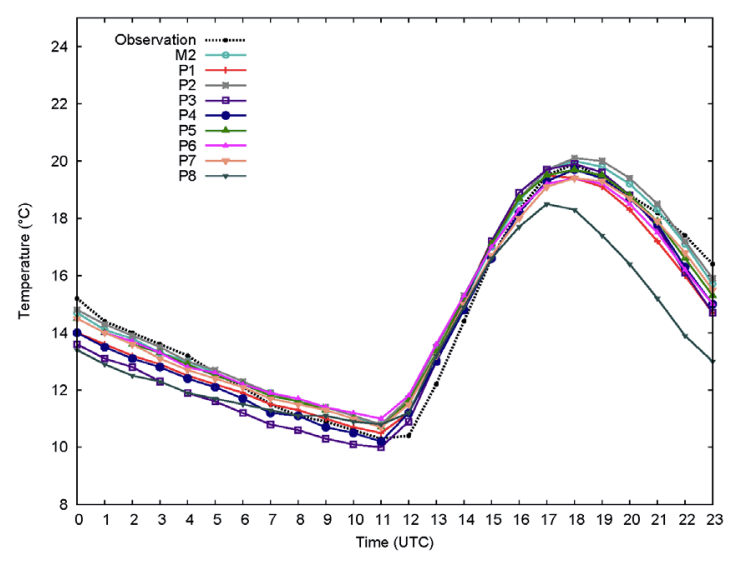

(a)

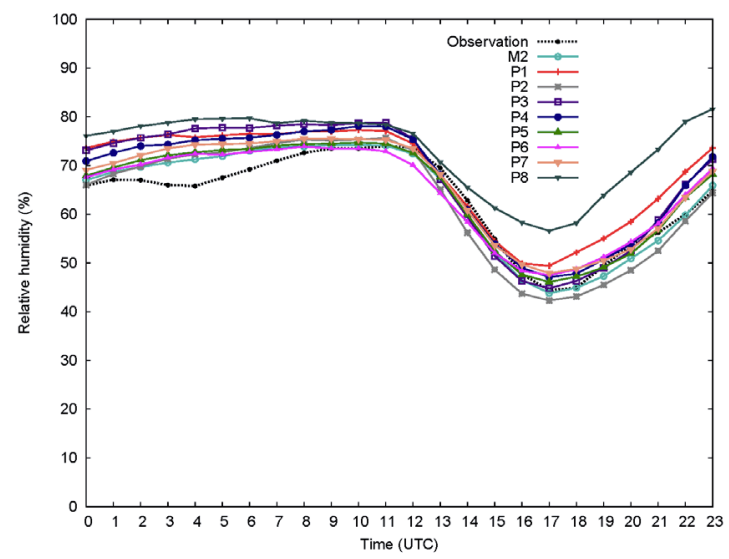

(c)

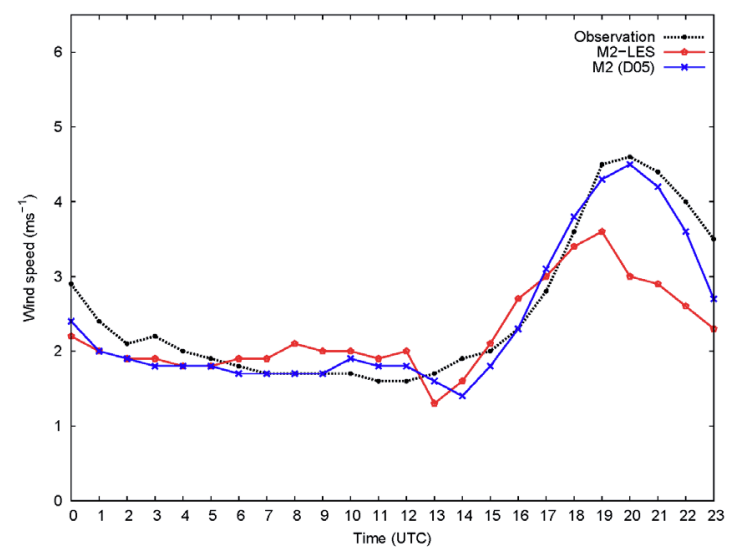

(e)

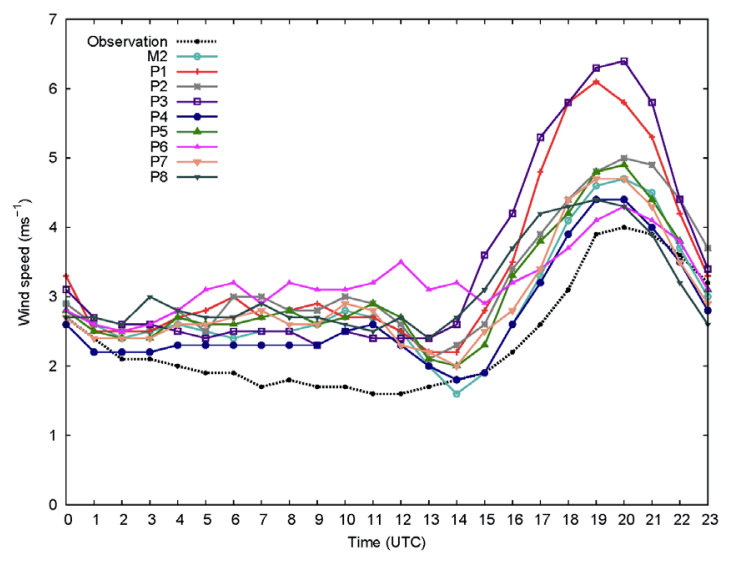

(b)

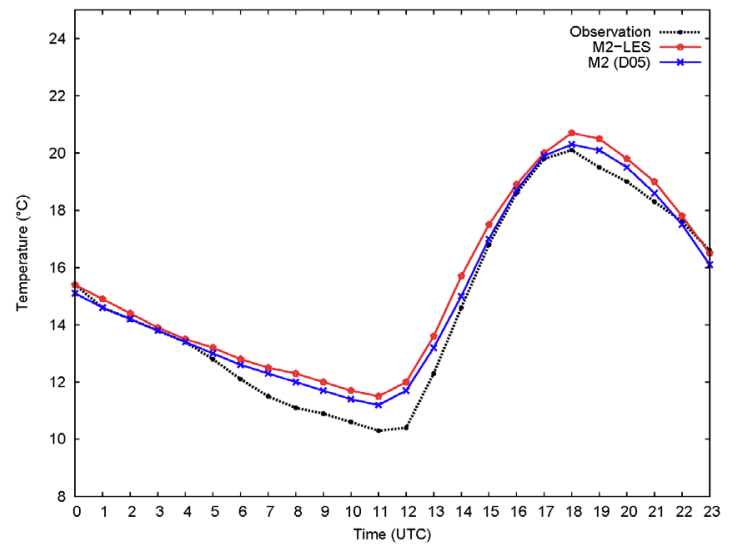

(d)

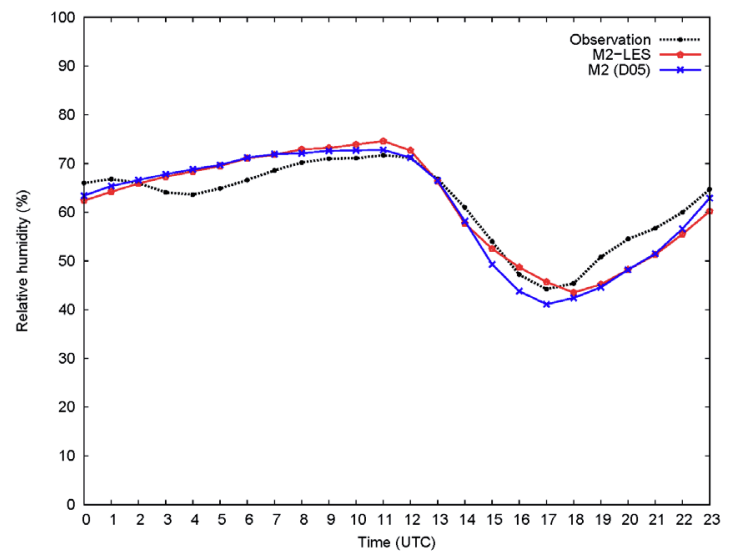

(f)

Figure 6. Daily evolution of the mean hourly temperature (a); wind speed (b) and relative humidity (c) for PBL experiments [left] and hourly evolution of temperature (d); wind speed (e) and relative humidity (f) for finer resolution experiments [right].

zation of orography-induced turbulence.

The model replicated temperature observations with a global index of agreement of 0.90. Not so precisely wind direction was predicted, but uncertainty of the prediction associated to this variable plays an important role.

Finally, a WRF-Large Eddy Simulation was included into the analysis, a modelling experiment with finer ho- 
rizontal resolution (333 m) over Bogotá centre (D05). This experiment was compared with M2 configuration and meteorological evaluation found that although the latter improved most metrics for all the meteorological parameters, there were not conclusive differences between them. These findings will allow us to couple WRFLES with the emission and photochemical models at a higher resolution as an area of work for the future. However, default WRF physiographic data sets (topography and land uses) were used for $333 \mathrm{~m}$ resolution simulations. This analysis may be extended in the future by including higher resolution data sets so that we can accurately evaluate model performance of the LES approach. To achieve conclusive results, both in WRF and WRF-LES simulations, it will be useful to extend this study to a large period.

\section{Acknowledgements}

This work has been developed within the framework of Santander Universities SME Internship Program and it was partly funded by the Spanish Government through PTQ-12-05244. The observations used in the study were obtained from the open access Red de Monitoreo y Calidad del Aire de Bogotá that belongs to the Secretaría Distrital de Ambiente de Bogotá.

\section{References}

[1] Ritter, M., Müller, D., Tsai, M.-Y. and Parlow, E. (2013) Air Pollution Modeling over Very Complex Terrain: An Evaluation of WRF-Chem over Switzerland for Two 1-Year Periods. Atmospheric Research, 132-133, 209-222. http://dx.doi.org/10.1016/j.atmosres.2013.05.021

[2] Larsen, B. (2004) Cost of Environmental Damage in Colombia: A Socio-Economic and Environmental Health Risk Assessment. Report Prepared for the Ministry of Environment, Housing and Land Development Republic of Colombia.

[3] Crutzen, P.J. (2004) New Directions: The Growing Urban Heat and Pollution "Island” Effect-Impact on Chemistry and Climate. Atmospheric Environment, 38, 3539-3540. http://dx.doi.org/10.1016/j.atmosenv.2004.03.032

[4] Lozano, N. (2004) Air Pollution in Bogotá, Colombia: A Concentration-Response Approach. Desarrollo y Sociedad, 54, 133-177.

[5] Zárate, E., Belalcázar, L.C., Clappier, A., Manzib, V. and Van den Bergh, H. (2007) Air Quality Modelling over Bogota, Colombia: Combined Techniques to Estimate and Evaluate Emission Inventories. Atmospheric Environment, 41, 6302-6318. http://dx.doi.org/10.1016/j.atmosenv.2007.03.011

[6] Rojas, N.Y. and Peñazola, N.E. (2012) Desagregación de inventarios de emisiones. Bogotá como caso de estudio, Editorial Académica Española.

[7] Arasa, R., Lozano-García, A. and Codina, B. (2014) Evaluating Mitigation Plans over Traffic Sector to Improve $\mathrm{NO}_{2}$ Levels in Andalusia (Spain) Using a Regional-Local Scale Photochemical Modelling System. Open Journal of Air Pollution, 3, 70-86. http://dx.doi.org/10.4236/ojap.2014.33008

[8] Jorquera, H. and Barraza, F. (2012) Source Apportionment of Ambient PM2.5 in Santiago, Chile: 1999 and 2004 Results. Science of the Total Environment, 435-436, 418-429. http://dx.doi.org/10.1016/j.scitotenv.2012.07.049

[9] Saide, P.E, Carmichael, G.R., Spak, N.S., Gallardo, L., Osses, A.E., Mena-Carrasco, M.A. and Pagowski, M. (2011) Forecasting Urban PM10 and PM2.5 Pollution Episodes in Very Stable Nocturnal Conditions and Complex Terrain Using WRF-Chem CO Tracer Model. Atmospheric Environment, 45, 2769-2780. http://dx.doi.org/10.1016/j.atmosenv.2011.02.001

[10] Jiménez, J. (2012) Urban Mixing Height in Mountains Terrain. An ARW Simulation for Aburra Valley (Colombia). Paper Presented at the $13^{\text {th }}$ Annual WRF Users, Workshop.

[11] Rincón, M.A. (2012) Acoplamiento del modelo de mesoescala WRF al modelo de calidad del aire Calpuff. PhD Thesis, Universidad Nacional de Colombia, Bogotá.

[12] Arasa, R. (2011) Modelització i simulació fotoquímica mesoscalar del transport del material particulat i gasos a l'atmosfera. PhD Thesis, Universitat de Barcelona, Barcelona.

[13] Krieger, J.R., Zhang, J., Atkinson, D.E., Shulski, M.D. and Zhang, X. (2009) Sensitivity of WRF Model Forecasts to Different Physical Parameterizations in the Beaufort Sea Region. 8th Conference on Coastal Atmospheric and Oceanic Prediction and Processes, San Diego, 10 January 2009.

[14] Hirabayashi, S., Kroll, C.N. and Nowak, D.J. (2011) Component-Based Development and Sensitivity Analyses of an Air Pollutant Dry Deposition Model. Environmental Modelling \& Software, 26, 804-816. http://dx.doi.org/10.1016/j.envsoft.2010.11.007

[15] Borge, R., Alexandrov, V., del Vas, J.J., Lumbreras, J. and Rodríguez, E. (2008) A Comprehensive Sensitivity Analysis of the WRF Model for Air Quality Applications over the Iberian Peninsula. Atmospheric Environment, 42, 8560- 
8574. http://dx.doi.org/10.1016/j.atmosenv.2008.08.032

[16] Arasa, R., Soler, M.R. and Olid, M. (2012) Numerical Experiments to Determine MM5/WRF-CMAQ Sensitivity to Various PBL and Land-Surface Schemes in North-Eastern Spain: Application to a Case Study in Summer 2009. International Journal of Environment and Pollution, 48, 105-116.

[17] Sanjay, J. (2008) Assessment of Atmospheric Boundary-Layer Processes Represented in the Numerical Model MM5 for a Clear Sky Day Using LASPEx Observations. Boundary-Layer Meteorology, 129, 159-177. http://dx.doi.org/10.1007/s10546-008-9298-6

[18] Srinivas, C.V., Bhaskar Rao, D.V., Yesubabu, V. and Venkatraman, B. (2012) Tropical Cyclone Predictions over the Bay of Bengal Using the High-Resolution Advanced Research Weather. Quarterly Journal of the Royal Meteorological Society, 139, 1810-1825. http://dx.doi.org/10.1002/qj.2064

[19] Hariprasad, K.B.R.R., Srinivas, C.V., Bagavath Singh, A., Vijaya Bhaskara Rao, S., Baskaran, R. and Venkatraman, B. (2014) Numerical Simulation and Intercomparison of Boundary Layer Structure with Different PBL Schemes in WRF Using Experimental Observations at a Tropical Site. Atmospheric Research, 145-146, 27-44. http://dx.doi.org/10.1016/j.atmosres.2014.03.023

[20] Skamarock, W.C., Klemp, J.B., Dudhia, J., Gill, D.O., Barker, D.M., Duda, M.G., Huang, X.-Y., Wang, W. and Powers, J.G. (2005) A Description of the Advanced Research WRF Version 3. NCAR Tech Notes-475 +STR.

[21] Jiménez-Guerrero, P., Parra, R. and Baldasano, J.M. (2007) Influence of Initial and Boundary Conditions for Ozone Modeling in Very Complex Terrains: A Case Study in the Northeastern Iberian Peninsula. Environmental Modelling \& Software, 22, 1924-1936.

[22] Zhang, Y., Liu, P., Pun, B. and Seigneur, C. (2006) A Comprehensive Performance Evaluation of MM5-CMAQ for the Summer 1999 Southern Oxidants Study Episode-Part I: Evaluation Protocols, Databases, and Meteorological Predictions. Atmospheric Environment, 40, 4825-4838. http://dx.doi.org/10.1016/j.atmosenv.2005.12.043

[23] Bravo, M., Mira, T., Soler, M.R. and Cuxart, J. (2008) Intercomparison and Evaluation of MM5 and Meso-NH Mesoscale Models in the Stable Boundary Layer. Boundary-Layer Meteorology, 128, 77-101. http://dx.doi.org/10.1007/s10546-008-9269-y

[24] Seaman, N., Gaudet, B., Zielonka, J. and Stauffer, D. (2009) Sensitivity of Vertical Structure in the Stable Boundary Layer to Variations of the WRF Model's Mellor-Yamada-Janjic Turbulence Scheme. Paper presented at the 10th WRF Users' Workshop, 23-26 June 2009.

[25] Pielke Sr., R.A. (2002) Mesoscale Meteorological Modeling. 2nd Edition, Academic Press, San Diego.

[26] Carvalho, D., Rocha, A., Gómez-Gesteira, M. and Santos, C. (2012) A Sensitivity Study of the WRF Model in Wind Simulation for an Area of High Wind Energy. Environmental Modelling \& Software, 33, 23-34. http://dx.doi.org/10.1016/j.envsoft.2012.01.019

[27] Denby, B., Larssen, S., Guerreiro, C., Douros, J., Moussiopoulos, N., Fragkou, L., Gauss, M., Olesen, H. and Miranda, A.I. (2008) Guidance on the Use of Models for the European Air Quality Directive. ETC/ACC Report.

[28] Emery, C. and Tai., E. (2001) Enhanced Meteorological Modeling and Performance Evaluation for Two Texas Ozone Episodes. Final Report Submitted to Texas Natural Resources Conservation Commission, prepared by ENVIRON, International Corp., Novato.

[29] Jiménez-Guerrero, P., Jorba, O., Balsadano, J.M. and Gassó, S. (2008) The Use of a Modelling System as a Tool for Air Quality Management: Annual High-Resolution Simulations and Evaluation. Science of the Total Environment, 390, 323-340. http://dx.doi.org/10.1016/j.scitotenv.2007.10.025

[30] Soler, M.R., Arasa, R., Merino, M., Olid, M. and Ortega, S. (2011) Modelling Local Seabreeze Flow and Associated Dispersion Patterns over a Coastal Area in North-East Spain: A Case Study. Boundary-Layer Meteorology, 140, 37-56. http://dx.doi.org/10.1007/s10546-011-9599-z

[31] Mlawer, E.J., Taubman, S.J., Brown, P.D., Iacono, M.J. and Clough, S.A. (1997) Radiative Transfer for Inhomogeneous Atmosphere: RRTM, a Validated Correlated-k Model for the Long-Wave. Journal of Geophysical Research, 102, 16663-16682. http://dx.doi.org/10.1029/97JD00237

[32] Dudhia, J. (1989) Numerical Study of Convection Observed during the Winter Monsson Experiment Using a Mesoscale Two-Dimensional Model. Journal of Atmospheric Sciences, 46, 3077-3104. http://dx.doi.org/10.1175/1520-0469(1989)046<3077:NSOCOD>2.0.CO;2

[33] Chen, F. and Dudhia, J. (2001) Coupling an Advanced Land Surface-Hydrology Model with the Penn State-NCAR MM5 Modeling System. Part I: Model Implementation and Sensitivity. Monthly Weather Review, 129, 569-585. http://dx.doi.org/10.1175/1520-0493(2001)129<0569:CAALSH>2.0.CO;2

[34] Kain, J.S. (2004) The Kain-Fritsch Convective Parameterization: An Update. Journal of Applied Meteorology, 43, 170181. http://dx.doi.org/10.1175/1520-0450(2004)043<0170:TKCPAU>2.0.CO;2

[35] Janjić, Z.I. (1994) The Step-Mountain Eta Coordinate Model: Further Developments of the Convection, Viscous 
Sublayer and Turbulence Closure Schemes. Monthly Weather Review, 122, 927-945. http://dx.doi.org/10.1175/1520-0493(1994)122<0927:TSMECM>2.0.CO;2

[36] Janjic, Z.I. (2000) Comments on Development and Evaluation of a Convective Scheme for Use in Climate Models. Journal of Atmospheric Sciences, 57, 3686. http://dx.doi.org/10.1175/1520-0469(2000)057<3686:CODAEO>2.0.CO;2

[37] Grell, G.A. and Freitas, S.R (2013) A Scale and Aerosol Aware Stochastic Convective Parameterization for Weather and Air Quality Modelling. Atmospheric Chemistry and Physics, 13, 23845-23893. http://dx.doi.org/10.5194/acpd-13-23845-2013

[38] Hong, S.-Y., Dudhia, J. and Chen, S.-H. (2004) A Revised Approach to Ice Microphysical Processes for the Bulk Parameterization of Clouds and Precipitation. Monthly Weather Review, 132, 103-120. http://dx.doi.org/10.1175/1520-0493(2004)132<0103:ARATIM>2.0.CO;2

[39] Lin, Y. and Colle, B.A. (2011) A New Bulk Microphysical Scheme That Includes Varying Degree of Riming and Particle Habits. Monthly Weather Review, 139, 1036-1047. http://dx.doi.org/10.1175/2010MWR3299.1

[40] Morrison, H., Thompson, G. and Tatarskii, V. (2009) Impact of Cloud Microphysics on the Development of Trailing Stratiform Precipitation in a Simulated Squall Line: Comparison of One- and Two-Moment Schemes. Monthly Weather Review, 137, 991-1007. http://dx.doi.org/10.1175/2008MWR2556.1

[41] Pérez, C., Jiménez, P., Jorba, O., Sicard, M. and Baldasano, J. (2006) Influence of the PBL Scheme on High-Resolution Photochemical Simulations in an Urban Coastal Area over the Western Mediterranean. Atmospheric Environment, 40, 5274-5297. http://dx.doi.org/10.1016/j.atmosenv.2006.04.039

[42] Hong, S.-Y., Noh, Y. and Dudhia, J. (2006) A New Vertical Diffusion Package with an Explicit Treatment of Entrainment Processes. Monthly Weather Review, 134, 2318-2341. http://dx.doi.org/10.1175/MWR3199.1

[43] Pleim, J.E. (2007) A Combined Local and Non-Local Closure Model for the Atmospheric Boundary Layer. Part I: Model Description and Testing. Journal of Applied Meteorology and Climatology, 46, 1383-1395. http://dx.doi.org/10.1175/JAM2539.1

[44] Sukoriansky, S., Galperin, B. and Perov, V. (2005) Application of a new Spectral Theory of Stable Stratified Turbulence to the Atmospheric Boundary Layer over Sea Ice. Boundary-Layer Meteorology, 117, 231-257. http://dx.doi.org/10.1007/s10546-004-6848-4

[45] Nakanishi, M. and Niino, H. (2006) An Improved Mellor-Yamada Level 3 Model: Its Numerical Stability and Application to a Regional Prediction of Advection Fog. Boundary-Layer Meteorology, 119, 397-407. http://dx.doi.org/10.1007/s10546-005-9030-8

[46] Grenier, H. and Bretherton, C.S. (2001) A Moist PBL Parameterization for Large-Scale Models and Its Application to Subtropical Cloud-Topped Marine Boundary Layers. Monthly Weather Review, 129, 357-377. http://dx.doi.org/10.1175/1520-0493(2001)129<0357:AMPPFL>2.0.CO;2

[47] Bougeault, P. and Lacarrère, P. (1989) Parameterization of Orography-Induced Turbulence in a Mesobeta-Scale Model. Monthly Weather Review, 117, 1872-1890. http://dx.doi.org/10.1175/1520-0493(1989)117<1872:POOITI>2.0.CO;2

[48] Bretherton, C.S. and Park, S. (2009) A New Moist Turbulence Parameterization in the Community Atmosphere Model. Journal of Climate, 22, 3422-3448. http://dx.doi.org/10.1175/2008JCLI2556.1

[49] Angevine, W.M., Jiang, H. and Mauritsen, T. (2010) Performance of an Eddy Diffusivity-Mass Flux Scheme for Shallow Cumulus Boundary Layers. Monthly Weather Review, 138, 2895-2912. http://dx.doi.org/10.1175/2010MWR3142.1

[50] Ching, J. (2011) Fine Scale Meteorology \& Air Quality Models. Urban Forecasting, Planning and Assessment Tools. Croucher Advanced Study Institute, Hong Kong.

[51] Kusaka, H., Kondo, H., Kikegawa, Y. and Kimura, F. (2001) A Simple Singer-Layer Urban Canopy Model for Atmospheric Models: Comparison with Multi-Layer and Slab Models. Boundary-Layer Meteorology, 101, 329-358. http://dx.doi.org/10.1023/A:1019207923078

[52] Martilli, A., Grossmann Clarke, S., Tewari, M. and Manning K.W. (2009) Description of the Modifications Made in WRF.3.1 and Short User's Manual of BEP.

[53] Isakov, V., Irwin, J.S. and Ching, J. (2006) Using CMAQ for Exposure Modeling and Characterizing the Subgrid Variability for Exposure Estimates. Journal of Applied Meteorology and Climatology, 46, 1354-1371. http://dx.doi.org/10.1175/JAM2538.1

[54] Stein, A.F., Isakov, V., Godowitch, J. and Draxler, R.R. (2006) Combining HYSPLIT and CMAQ to Resolve Urban Scale Features: An Example of Application in Houston, TX. CMAS Conference.

[55] Isakov, V., Touma, J.S., Burke, J., Lobdell, D.T., Palma, T., Rosenbaum, A. and Özkaynak, H. (2009) Combining Regional- and Local-Scale Air Quality Models with Exposure Models for Use in Environmental Health Studies. Journal of Air and Waste Management, 59, 461-472. http://dx.doi.org/10.3155/1047-3289.59.4.461 
[56] Herwehe, J., Ching, J.S. and Swall, J.L. (2004) Quantifying Subgrid Pollutant Variability in Eulerian Air Quality Models. 5th Symposium on the Urban Environment, Vancouver, 23-27 August 2004.

[57] Queen, A. and Zhang, Y. (2008) Examining the Sensitivity of MM5-CMAQ Predictions to Explicit Microphysics Schemes and Horizontal Grid Resolutions, Part II-PM Concentrations and Wet Deposition Predictions. Atmospheric Environment, 42, 3856-3868. http://dx.doi.org/10.1016/j.atmosenv.2007.12.066 